\title{
Influence of Canopy Architecture on the Light Interception, Photosynthetic and Biomass Productivity in Irrigated Elite Sri Lankan Rice Varieties
}

\author{
A.N.M. Mubarak*, Musthapha Mufeeth, M.R. Roshana and A.D.N.T. Kumara
}

Received: 02 ${ }^{\text {nd }}$ March $2021 /$ Accepted: 06 $6^{\text {th }}$ November 2021

\begin{abstract}
Purpose: Canopy light interception and extinction play a crucial role in determining crop yield. Developing new rice varieties with improved canopy architecture along with modified intrinsic photosynthetic mechanisms will ensure the global food security. However, a comprehensive understanding of local rice varieties addressing on such avenues have not been reported. Hence, our pioneering experiments were carried out to elucidate such underlying properties among locally developed two elite rice varieties viz; At-362 and Bg 94-1 grown in the Ampara district of Sri Lanka.
\end{abstract}

Research Method: The field experiment was carried out at the Agro Tech Park, Malwatta $\left(7^{\circ} 20^{\prime} \mathrm{N}\right.$ and $81^{\circ} 44^{\prime} E$ altitude $16.0 \mathrm{~m}$ above sea level) between October 2019 to January 2020 implemented with Randomized Complete Block Design with four replicates. The Photosynthetically Active Radiation (PAR) distribution on the above and below canopy level was measured during the pre and post-anthesis stages. Then leaf stomatal conductance, chlorophyll fluorescence parameters and the chlorophyll content were also measured. At harvest, the final biomass produced were compared.

Findings: The result revealed that variety At-362 had a higher Leaf Area Index (LAI) of 2.64 at pre anthesis and tend to decline at the latter part of their growth cycle. The striking feature was the extinction coefficient (k) seems to be much lower (0.47) in the At-362 variety than the Bg 94-1 (0.60) depicting that the former has produced vertical leaves (erect-leaf type) while the latter tends to produce horizontal leaf plans in the canopy. Hence, light attenuation was high and eventually, the bottom canopy layer received much lower PAR. Furthermore, LAI had a strong negative correlation with understory PAR indicating that the canopy architecture with an improved light interception will lead to permit more light penetration and utilization through the improved quantum yield efficiencies than the horizontal canopies. Hence significantly $(p<0.05)$ improved above-ground biomass and panicle weight were observed in At-362.

Originality/value: This experiment depicts that rice yield could be further improved through introgression of canopy architectural features along with improved photosynthetic traits.

Keywords: Canopy architecture, extinction coefficient, leaf area index, rice

\section{INTRODUCTION}

Rice (Oryza sativa L.) belongs to the Poaceae family, is one of the most important cereal crops and acts as the primary source of staple food for more than half of the global population. Asian continent contributes approximately $90 \%$ of the world's rice production and is a staple meal for 2.7 billion people worldwide (Food and Agriculture Organization, 2018). Rice is a major portion of the Sri Lankan diets and the per capita consumption was around $122 \mathrm{~kg}$ per person/year in 2017 (Food and Agriculture Organization, 2017) which contributes $45 \%$ of the total calories.

\footnotetext{
* Department of Biosystems Technology, Faculty of Technology, South Eastern University of Sri Lanka, University Park, Oluvil \# 32360, Sri Lanka

anmubarak@seu.ac.lk

(D) https://orcid.org/0000-0002-1703-8609
} 
According to the national statistics, 1,116,933 ha of land were under paddy cultivation and the 3 $1 / 2$ month varieties were the most popular among farmers and account for $77 \%$ adaptation. Among those, the irrigated rice variety, At-362 contributes 198,001 ha $(17.73 \%)$, while the Bg 94-1 was cultivated in 37,658 ha $(3.37 \%)$ respectively (DOA, 2020). In terms of rice production, Ampara district is one of the popular rice growing regions in Sri Lanka and a total of 136,036 ha of paddy was cultivated predominantly with the At-362 and Bg-94-1 (DOA 2020) owing to their improved agronomic and yield characteristics. At-362 produces red long grains with an average plant height of $66.3 \pm 1.2 \mathrm{~cm}$, whereas $\mathrm{Bg} 94-1$ is a white long grain characterized with an average plant height of $56.58 \pm 1.7 \mathrm{~cm}$ (Begum et al., 2018; Department of Agriculture (DOA), 2020).

Crop yield is predominantly determined by the ability of capturing of resources by the canopies (e.g., light, water, and nutrients), the ability for conversion of resources into biomass and the extent of partitioning of biomass into harvesTable Oproduct (Wu et.al ., 2015). Particularly for rice, the optimized solar radiation, temperature, a balanced fertilizer, and water availability are important at pre and post anthesis stages to ensure increased final biomass and grain yield production (Fageria, 2007; Khalifa, 2009).

As such, photosynthetically active radiation (PAR) is a critical natural resource, essentially controls crop production. The amount of daily irradiance (light intensity, duration and quality) affects rice yield and quality (Ho et al., 2013). The light extinction properties have been well documented in many crop varieties (AzamAli and Squire, 2002). The first mathematical model was proposed by Monsi and Saeki (1953) on canopy photosynthesis in response to light attenuation. They demonstrated that under a given light climate, stand structures develop to maximize canopy photosynthesis. Leaf structure, orientation, and leaf area are the key determinants of canopy architecture (Hirose, 2005). This robust and effective model shows that light attenuation is almost exponential in randomly distributed crop canopies and further, the common form of the Beer-Lambert equation for light extinction was incorporated (Goudriaan, 1977). Hence, this simplified canopy light distribution model has led to develop other models viz canopy multilayer models (Monteith, 1965), the spherical leaf angle distribution model to describe canopy photosynthesis and crop Radiation Use Efficiency (de Pury and Farquhar, 1997) and 3D plant architecture model (Roupsard et al., 2008).

The leaf area and the Leaf Area Index (LAI) can be viewed as one of the main components in assessing the above mentioned crop models. LAI is the ratio of the total, onside leaf surface area of the canopy and the ground area corresponding to below canopy. Measuring LAI is vital for both farmers and plant scientist to monitor the growth and the wellbeing of the plants (Murchie et al., 2009). Several methods have been developed to measure LAI including the direct contact method, passive optical method and active remote sensing methods. Directed techniques are relatively laborious and time-consuming and destructive sampling is not necessarily feasible in small plot experiment. Sampling in indirect leaf area measurement such as using ceptometer (nondestructive passive optical method) is widely used in analyzing LAI and is widely recognized in the scientific communities and have been applied in large fields (Pokovai and Fodor, 2019). According to the previous findings, the variation in crop productivity and growth is closely linked to the amount of intercepted radiation, primarily determined by the leaf area index (LAI) (Ewert, 2004; Ahmad et al., 2009).

Considering those facts, crop modellers have proposed that upright leaves, large panicles and fewer tillers with a deeper root system are the ideal structures for rice (Virk, Khush and Peng, 2004). Deeper canopy layers lead to uniformity of light within the canopy setting and confer maximal net photosynthesis (Normile, 1999; Falster and Westoby, 2003). Canopy architectural traits include; plant height, number of leaves and tillers and leaf traits such as length, width and LAI, are inherently linked to the resulting light environment and since the photosynthetic rate is strongly light-dependent (Burgess et al., 2017). In cereal crops, improvement of leaf-level and canopy photosynthesis hold a great potential to increase biomass and yield (Murchie et al., 2009; Song et al., 2016). There by, determining 
the leaf-level functions considering the role of stomatal physiologies, density, and distribution are paramount as they are closely associated with gas diffusion into the leaf tissues that determines the rates of photosynthesis and transpiration rates (Lawson and Mathews, 2020). A recent study confirmed that modification of stomatal densities leads to improve leaf-level photosynthesis (Yu et al., 2016). However, links between canopy architectural traits and photosynthetic productivity are poorly understood for the field grown rice varieties in Sri Lanka. In recent studies, it has been found that the irrigated rice variety, At-362 produced superior biomass and grain yield than the Bg 94-1 (Begum et al., 2018), though a comprehensive understanding for such observation has not been reported. As such, this study hypothesized that elite rice varieties might have altered light interception and extinction properties that may lead to vary in biomass production.

Therefore, the present study was carried out to explore the relationship between light extinction, photosynthetic and biomass characteristics of At362 and Bg 94-1 locally developed irrigated rice varieties in Sri Lanka.

\section{MATERIALS AND METHODS}

The field trial was carried out between October 2019 to January 2020 at the Agro Tech Park, Malwatta $\left(7^{\circ} 20^{\prime} \mathrm{N}\right.$ and $81^{\circ} 44^{\prime} \mathrm{E}$ altitude $16.0 \mathrm{~m}$ above sea level) managed by the South Eastern University, located in the Ampara district of Sri Lanka. Agro-ecologically, this experimental site is classified under the dry zones (DL 2b, Natural resource management centre, Department of Agriculture, 2017) characterized with sandy loam soils which typically receive an annual rainfall of $1600 \mathrm{~mm}$, predominantly through the north-east monsoon (October-December). To explore the climatic data for this experimental site, nine-year meteorological data were collected (between 2010 and 2018) from the regional meteorological station (Pottuvil) of the Department of Meteorology of Sri Lanka. Subsequently, calculated the mean monthly rainfall $(\mathrm{RF})$, temperature and relative humidity $(\mathrm{RH})$ received at the experimental site.

\section{Experimental Design}

The field experiment was laid out in randomized complete block design to minimize the soil fertility variation. Two commercially popular rice varieties namely At-362 and Bg 94-1 were planted with four replicates in each plot sizes of $5 \mathrm{~m} \times 5 \mathrm{~m}$.

\section{Field Measurements}

Plant physiological parameters were carried out to quantify the traits during the pre and postanthesis stages of rice varieties. The pre-anthesis measurements were focused at 50-55 days after field planting while the post-anthesis at 70-75 days. Leaf stomatal conductance was measured on 10 randomly selected plants per treatment at the widest part of flag leaves employing leaf porometers (SC-1, Decagon Devices Inc, USA). Before taking measurements, the instrument was calibrated each time according to instructions given by the manufacturer under a different set of environmental conditions to ensure accurate measurements.

A ceptometer (LP- 80, AccuPAR, Meter Group Inc, USA) was used to measure the above $\left(I_{0}\right)$ and below canopy (I) photosynthetically active radiation (PAR). Before the field measurements, the parameters such as the latitudes $\left(7.3^{\circ} \mathrm{N}\right)$, longitudes $\left(81.7^{\circ} \mathrm{E}\right)$ were manually fed to the instrument and the leaf distribution was set at 1.00 . Then the calibration was performed as per the manufacturer's instruction on an hourly basis. The external PAR sensor was used to measure the above canopy light intensity, while the below canopy light levels were taken at $5 \mathrm{~cm}$ above the ground level using the ceptometer probes (Pokovai and Fodor, 2019). Here, at least 8-10 measurements per plot were made during the cloudless clear sky to minimize the proportion of diffuse radiation into the plant canopy. Each PAR values were measured by placing the probe parallel and perpendicular positions to the crop rows, by which scanning approximately $0.6 \mathrm{~m}^{2}$ of canopies.

Based on the ceptometer readings, the Leaf Area Index (LAI) was estimated based on the ratio of two PAR levels. Moreover, light extinction 
coefficients $(k)$ for radiation was calculated by employing equation (1) as previously described by Monsi and Saeki (1953). Here the $L$ represents the LAI of a particular crop canopy.

$$
I / I_{o}=e^{-k L}
$$

Then to find the $\mathrm{k}$ values for each rice crop canopies, graphs were plotted with $\ln \left(I / I_{o}\right)$ against LAI which determines the architecture of crop canopies (Azam-Ali and Squire, 2002). Then the fraction of radiation intercepted by the crop canopy (f) was calculated from the knowledge of L (equation 2).

$$
f=1-e^{(-k L)}
$$

Moreover, the morphological characteristics including the dimensions (length and width) of five flag leaves (FL) and the penultimate leaves (leaf positioned just below the FL) per treatment were recorded. Then the actual leaf area of those leaves was measured using a handheld leaf area meter (LI-3100C, Lincoln, USA). Subsequently, the amount of chlorophyll presented in the flag leaves was quantified using SPAD meters (SPAD 502 plus Chlorophyll Meter, Spectrum technologies Inc, USA). Following this, the quantum yield was measured using the chlorophyll fluorescence technique (FluroPen FP-100 Photon Systems Instruments, Czech Republic) in both the light- and the dark-adapted flag leaves.

At harvest, the biomass production was compared by employing a quadrate of $0.5 \mathrm{~m} \times 0.5 \mathrm{~m}$ to collect plant samples from the field $\left(0.25 \mathrm{~m}^{2}\right)$. Then they were separated into panicle and straw parts before the samples were placed in a dry oven at $80^{\circ} \mathrm{C}$ until constant dry weights were obtained. From those readings, the above-ground dry matter (AGDM) and harvest index were calculated. The data generated from the above experiments were analyzed using SAS (version 9.1.3) software package. Prior to this, the data mentioned here met the assumption of constant variance and normal distribution of residuals. Then the ANOVA was performed to test the differences between varieties at a $5 \%$ significant level. Further, a correlation matrix was used to investigate the relationships between $\ln (\mathrm{I} / \mathrm{Io})$ and LAI.

\section{RESULTS AND DISCUSSION}

Based on the meteorological data (20102018), the annual mean rainfall received at the experimental site was $1,525.6 \pm 33.4 \mathrm{~mm}$ whereby it was distributed unevenly among the months. Typically, rainfall increases at the onset of September, then reaches peak in December. Thereafter, a sharp decline was seen until April, then mild rainfall $(75.0 \mathrm{~mm})$ received in May (two peaks). This was true for the year 2019/2020 cultivation as our field trials were carried out between October to January (typically Maha season) that assured sufficient precipitation was received through the North-Eastern monsoon (Annexure 1). Before the initiation of the trial, the tillage operations were performed in September with the aid of irrigation water received through local agricultural tanks.

The mean air temperatures were calculated from the minimum and maximum temperatures from meteorological data. The annual mean temperature for the experimental site was $30.3 \pm 0.5{ }^{\circ} \mathrm{C}$, here the highest temperatures were recorded between May to July while the temperature slightly declined towards October. Hence, comparably reduced rates of evaporation from soil and transpiration from the plant canopies are expected during the crop vegetative and reproductive growth.

\section{Light penetration through the crop canopy}

During the field measurement at the pre anthesis stage, the mean above canopy PAR of At-362 and $\mathrm{Bg}$ 94-1 were 2197.6 $\pm 27.7 \mu_{\mathrm{molm}}{ }^{-2} \mathrm{~s}^{-1}$ and $1770.8 \pm 42.8 \mu \mathrm{molm}^{-2} \mathrm{~s}^{-1}$ (Table 01). Here, the variety At-362 received a significantly $\left(\mathrm{F}_{1,59}\right.$ $=10.879 ; \mathrm{p}=0.002$ ) lower amount of PAR at ground levels $\left(574.8 \pm 39.9 \mu^{2} \mathrm{molm}^{-2} \mathrm{~s}^{-1}\right)$ than the Bg 94-1. Hence, the present results indicated that the extinction of light levels significantly $\left(\mathrm{F}_{1,59}=52.155 ; \mathrm{p}=0.0001\right)$ vary between the rice canopies.

This implies that $73.4 \%$ of light had been diminished $\left(1613 \pm 29.7 \mu_{\mathrm{molm}}^{-2} \mathrm{~s}^{-1}\right)$ and utilized by the canopy in the former, while in the latter was $67.5 \%$ (Table 01). However, this scenario 
has significantly changed in the post-anthesis stage which had a reduced amount of light, as light had been absorbed by the At-362 canopy (40.4\%) and $\mathrm{Bg}$ 94-1(41.4\% ) respectively, though, insignificant changes were seen at this stage. When compared the LAI, variety At-362 produced significantly $\left(\mathrm{F}_{1,59}=6.783 ; \mathrm{p}=0.01\right)$ higher LAI of 2.64 at pre anthesis stage while in the counterpart $\mathrm{Bg}$ 94-1 variety produced much lower (2.20). With canopy age, the LAI had substantially reduced in both varieties at post anthesis stage, a lower LAI was noticed. According to Beer-Lambert's light extinction theory, the attenuation of light depends on the arrangement of canopy architecture. A crop with narrow and erect leaves tends to have lower $k$-values than a crop with more horizontally displayed leaf arrangement (Azam-Ali and Squire, 2002).

To find out of $k$-values of each crop strands, graphs were constructed which showed a linear negative relationship between the natural log scale of radiation transmission ( $\ln (\mathrm{I} / \mathrm{Io})$ ) and LAI at pre and post-anthesis stage (Fig la \& b). The extinction coefficient $(k)$ value of At 362 was relatively smaller $\left(k_{A t}=0.48\right)$ while, the variety Bg 94-1 remained at increased values $\left(k_{B g}=0.59\right)$. This evidence depicts that the former rice variety possessed vertically arranged leaves (erect type), while the latter counterpart tends to possess leaf blades with the horizontal plan.

Theoretically, a low $k$ indicates that much radiation can reach the bottom of the canopy. Conversely, a high $\mathrm{k}$ represents little radiation that can be penetrated the understory of the canopy. Theoretically, $k$ is dependent on the leaf inclined angle $(\alpha)$ and solar zenith angle $(\theta)$ (Campbell, 1986). This scenario was much pronounced at the post-anthesis stage at 70 days after field planting. Both varieties had displayed lower $k$-values ( 0.13 and 0.20 respectively) indicating that leaves inclined further vertically when the crop canopies at their latter stages. Moreover, Zhang et al. (2014) found that horizontal leaves commonly possess a $k$-value of $0.7-1.0$, whereas vertically inclined leaves give $0.3-0.5$.

Our findings are in line with the study of Sanoh et al., (2006) who found the $k$ value of rice in the ranges of $0.5-0.7$, conversely, a higher $k$ indicates that only a little radiation can penetrate the understory of the canopy (Chang et al., 2019). Further, the PAR absorption rate of the canopy is impacted by leaf orientation, sun elevation in the sky (Nobel, Forseth and Long, 1992). Thus, the increased $k$ value have knock-on effects by creating mutual shading in the corresponding leaf when flatter canopy architecture has prevailed.

Table 01: Amount of light (PAR) received at above and below canopy levels, PAR extinction and LAI characteristics at pre and post-anthesis stages of At-362 and Bg 94-1 rice cultivars

\begin{tabular}{|c|c|c|c|c|c|c|}
\hline \multirow[t]{2}{*}{ Variety } & \multirow[t]{2}{*}{$\begin{array}{l}\text { Measuring } \\
\text { Stage }\end{array}$} & \multicolumn{2}{|c|}{ PAR levels $\left(\mu \mathrm{molm}^{-2} \mathrm{~s}^{-1}\right)$} & \multirow[t]{2}{*}{$\begin{array}{c}\text { Amount of PAR } \\
\text { extinction }\left(\mu \mathrm{molm}^{-2} \mathrm{~s}^{-1}\right)\end{array}$} & \multirow[t]{2}{*}{$\begin{array}{l}\% \text { of PAR } \\
\text { extinction }\end{array}$} & \multirow[t]{2}{*}{ LAI } \\
\hline & & Above canopy & Below canopy & & & \\
\hline \multirow{3}{*}{ Bg 94-1 } & Pre-anthesis & $1770.8 \pm 42.8$ & $672.5 \pm 29.71$ & $1195.9 \pm 65.2$ & $67.5 \%$ & $2.22 \pm 0.13$ \\
\hline & & & & & & \\
\hline & Post-anthesis & $1953.5 \pm 26.9$ & $1144.9 \pm 16.3$ & $808.6 \pm 34.5$ & $41.4 \%$ & $2.00 \pm 0.08$ \\
\hline \multirow{2}{*}{ At-362 } & Pre-anthesis & $2197.6 \pm 27.7$ & $574.8 \pm 39.9 *$ & $1613.3 \pm 29.7 *$ & $73.4 \% *$ & $2.64 \pm 0.11 *$ \\
\hline & Post-anthesis & $2032.1 \pm 42.4$ & $1230.8 \pm 19.3$ & $820.7 \pm 44.3$ & $40.4 \%$ & $1.95 \pm 0.05$ \\
\hline
\end{tabular}

The symbol (*) indicates significant differences between pre and post anthesis stages of rice cultivars $(p$-value $<0.05)$. The values correspond to the means of each parameter $\pm S E$. 


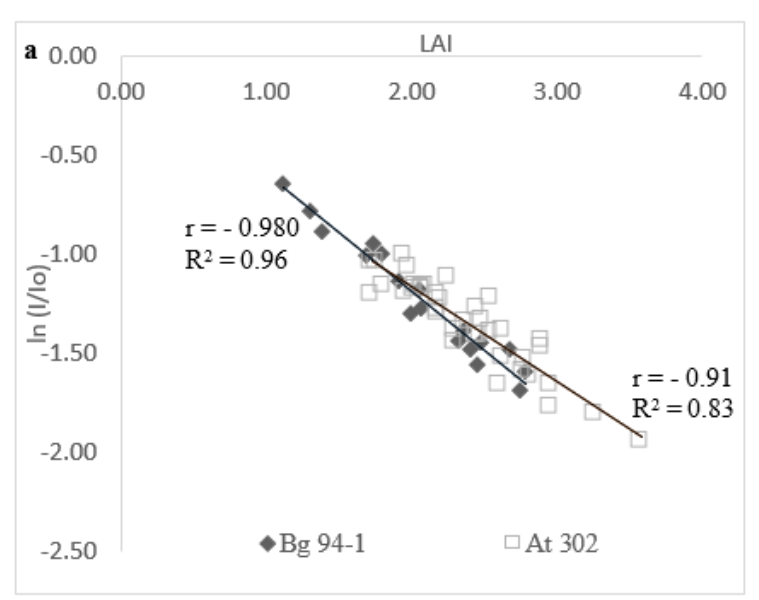

Figure 01a: Relationship between canopy In(I/ I0) and LAI at pre-anthesis stage of Bg 94-1 and At 302 rice varieties.

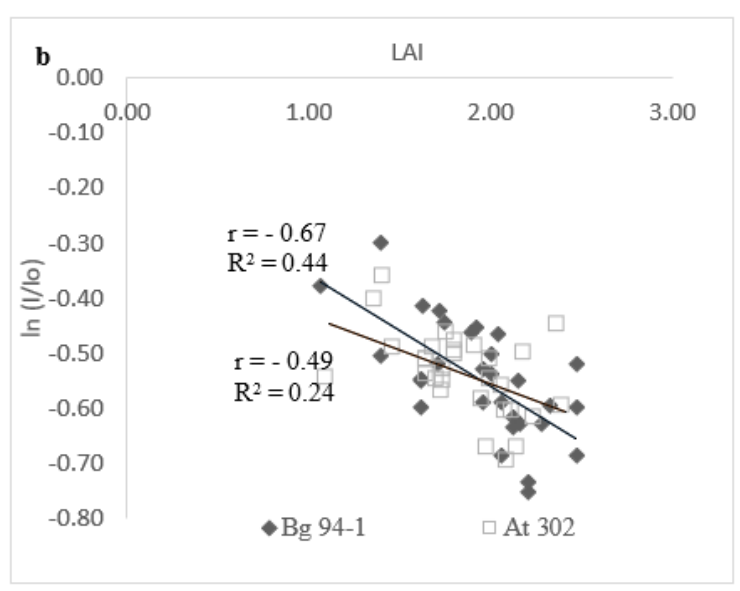

Figure 01b: Relationship between canopy $\operatorname{In}(\mathrm{I} /$ I0) and LAI at post-anthesis stage of $\mathrm{Bg}$ 94-1 and At 302 rice varieties.
Furthermore, the fractional interception of radiation intercepted by the crop canopy $(f)$ was estimated. It was found in $\mathrm{Bg}$ 94-1 $\left(f_{B g}\right.$ at preanthesis stage $=0.73, f_{B g}$ at post-anthesis stage $=0.33$ ) while similar values were observed in At $362\left(f_{A t}\right.$ at pre-anthesis $=0.72, f_{A t}$ at postanthesis $=0.21)$. However, it was interesting to note that $k$ values of At-362 were lower, as a result the occurrence of light interception within the canopy tent to absorb more due to its erected leaf nature. Pradhan et al. (2018) propose that when intercepted radiation is higher, that had directly increased the photosynthetic rates when other plant growth factors remain in optimal conditions, it will eventually improve the aboveground biomass production.

To explore how canopy architecture influences photosynthesis and light interception at the whole canopy level, the correlation between the LAI and PAR ${ }_{\text {Below }}$ was carried out and found strong correlation at both stages of the tested rice varieties (Fig.2). This indicates the importance of maintaining the higher leaf canopies with the arrangement of the leaves. Our finding is in line with previous work where the total canopy light interception is negatively correlated to measure LAI at both growth stages (Burgess et al., 2017). Increasing LAI within a canopy could increase the PAR interception by crop in a productive manner, while this becomes true when the leaf arrangement on the main culm and the plan area are arranged in optimum positions to enhance light penetration further deeper into the canopy.
The measurements on leaf dimensions were performed (Table 02) and revealed that the At362 variety had produced a larger flag leaf length of $33.51 \pm 0.80 \mathrm{~cm}$ and width $(11.20 \pm 0.30 \mathrm{~mm})$ and confirmed these produced increased leaf size than the Bg 94-1 variety. When compared the leaf area using LI-3000C porTable 0leaf area meter, it was revealed that the At-362 possessed a significantly $(\mathrm{F} 1,39=5.639 ; \mathrm{p}=0.024)$ increased flag-leaf area $\left(33.66 \pm 2.11 \mathrm{~cm}^{2}\right)$ than the counterpart. Though, as it was outlined earlier, the $k$-value for At-362 was lower and thus implies an erect type leaves with greater leaf areas appear to provide an increased photosynthesis surface. Conversely, the penultimate leaf traits in both rice varieties remained the same, as this shows an important role of flag leaves at a flowering stage that can convert photosynthates into useful biomass production.

The trial further compared the chlorophyll contents among the flag leaves, both rice varieties had increased chlorophyll content ( $>37.0$ SPAD values) but no significant difference was seen among them (Table 03), implying that both rice varieties had sufficient Nitrogen nutrients to synthesize chlorophyll molecules and other photosynthetic related proteins as to perform light-dependent and independent reactions successfully in the chloroplasts. Here, the supply of a sufficient amount of nitrogen will ensure the persistence of enzyme rubisco for catalyzing carbon acceptor molecule in the Calvin cycle (Taiz et al., 2015). 

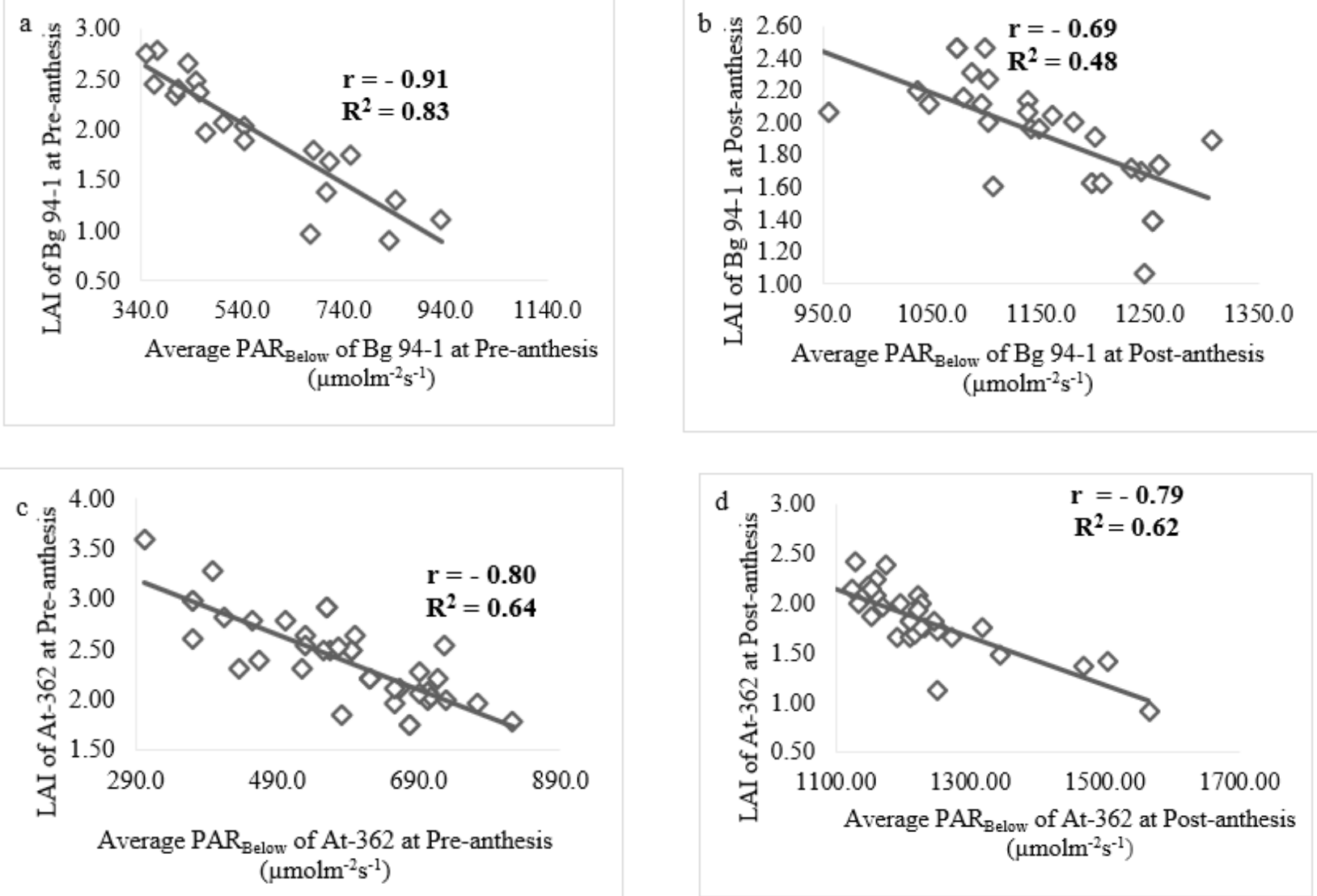

Figure 02: Relationship between leaf area index (LAI) and below canopy PAR (PARBelow) (a) Pre-anthesis of Bg 94-1 (b) Post-anthesis of Bg 94-1 (c) Pre-anthesis of At-362 (d) Postanthesis of At-362. The $r$ indicates the relationship between LAI and PARBelow. The $\mathbf{R}^{2}$ indicate the portion of the total variability that is explained by the fitted linear model.

Table 02: Leaf morphological traits and the actual leaf area of At-362 and Bg 94-1 varieties

\begin{tabular}{ccc}
\hline \multirow{2}{*}{ Leaf morphological traits } & \multicolumn{2}{c}{ Rice cultivar } \\
\cline { 2 - 3 } & At-362 & Bg 94-1 \\
\hline Flag leaf area $\left(\mathrm{cm}^{2}\right)$ & $33.66 \pm 2.11^{*}$ & $23.26 \pm 1.88$ \\
Penultimate leaf area $\left(\mathrm{cm}^{2}\right)$ & $32.18 \pm 1.52$ & $27.56 \pm 2.04$ \\
Flag leaf length $(\mathrm{cm})$ & $33.51 \pm 0.80$ & $32.56 \pm 1.59$ \\
Flag leaf width $(\mathrm{mm})$ & $11.20 \pm 0.30$ & $10.75 \pm 0.42$ \\
Penultimate leaf length $(\mathrm{cm})$ & $39.40 \pm 0.89$ & $37.39 \pm 1.41$ \\
Penultimate leaf width $(\mathrm{mm})$ & $9.55 \pm 0.34$ & $9.30 \pm 0.36$ \\
\hline
\end{tabular}

The symbol (*) indicates significant differences between rice cultivars ( $p$ value $<0.05)$. The values correspond to the means of each parameter \pm SEM, $(n=20)$. 


\begin{tabular}{|c|c|c|c|c|}
\hline Table 03: & \multicolumn{4}{|c|}{$\begin{array}{l}\text { Quantum yield, leaf chlorophyll content and stomatal conductance of At-362 and Bg 94-1 } \\
\text { varieties }\end{array}$} \\
\hline \multirow{2}{*}{\multicolumn{2}{|c|}{ Measured parameter }} & \multicolumn{2}{|c|}{ Rice cultivar } & \multirow{2}{*}{$\mathrm{n}$} \\
\hline & & At-362 & Bg 94-1 & \\
\hline & Quantum Yield & $0.68 \pm 0.01^{*}$ & $0.65 \pm 0.01$ & 20 \\
\hline & lorophyll content (SPAD value) & $37.81 \pm 0.94$ & $37.19 \pm 2.02$ & 20 \\
\hline \multicolumn{2}{|c|}{ Stomatal conductance $\left(\mu \mathrm{mol} \mathrm{m} \mathrm{m}^{-2} \mathrm{~s}^{-1}\right)$ at pre-anthesis } & $2229.7 \pm 102.5^{*}$ & $2632.7 \pm 59.2$ & 40 \\
\hline \multicolumn{2}{|c|}{ Stomatal conductance $\left(\mu \mathrm{mol} \mathrm{m}{ }^{-2} \mathrm{~s}^{-1}\right)$ at post-anthesis } & $723.2 \pm 20.2 *$ & $2436.9 \pm 93.6$ & 40 \\
\hline
\end{tabular}

The symbol (*) indicates significant differences between rice cultivars (p-value $<0.05)$. The values correspond to the means of each parameter $\pm S E$.

Moreover, when compared the quantum yield $\left(Q_{y}\right)$ in flag leaves, the variety At-362 had displayed significantly $\left(\mathrm{F}_{1,59}=8.447 ; \mathrm{p}=0.005\right)$ higher $\mathrm{Q}_{\mathrm{y}}$ than the Bg 94-1 indicating that the At362 had possessed an improved photosynthetic efficiency to capture the light photons then to convert them to useful photosynthetic products as glucose. Hou et al. (2017) claim that the ratio of the number of photons emitted to the number of photons absorbed and considered as a measure of photosystem II efficiency (PS II). Thus, the At-362 can intercept lighter quantum, which can serve as the driving force to the light-dependent photosynthetic reactions and the subsequent light-independent reactions that involve in the Calvin-Benson cycles. This observations are particularly important to PS II embedded in the thylakoid membrane where the absorbed photons are utilized for the splitting of water molecules which essentially produces the $\mathrm{H}^{+}$ions to initiate ion gradient within the thylakoid lumen of chloroplasts (Taiz et al., 2015; Hou et al., 2017). This phenomenon may be further useful in the production of sufficient ATPs and NADPs generated in the former stage and be useful in the Calvin and Benson cycle. Here, the initiating molecule RuBP accepts $\mathrm{CO}_{2}$ in the presence of catalyst Rubisco enzymes to follow the remainder process that may lead to a substantial sucrose production. Once a sufficient amount of sucrose is produced in the day time, while in the dark, it triggers efficient carbohydrate metabolism within the cytosols (Murchie et al., 2009; Taiz et al., 2015) so as the larger amount of starch is stored in the sinks (spikelet) that certainly will improve biomass and grain yield.
The flag leaf stomatal conductance (gs) of At362 displayed significantly lower than Bg 94-1 at both pre anthesis stage $\left(\mathrm{F}_{1,79}=16.254 ; \mathrm{p}=\right.$ $0.000)$ and post anthesis stage $\left(F_{1,79}=411.701\right.$; $\mathrm{p}=0.000$ ) (Table 03). The lower stomatal conductance featured in cereal crops may indicate the drought tolerance characteristics (Lawson and Mathews, 2020), thereby At-362 variety might possess inherently superior morphological and photosynthetic properties than the $\mathrm{Bg} 94-1$ variety.

At harvest, the mean above-ground biomass per unit land area (AGDM) was measured by considering their shoot weight. The mean AGDM for At-362 was significantly higher $\left(\mathrm{F}_{1,37}=21.463 ; \mathrm{p}=0.000\right)$ and produced 1302.3 $\pm 153.5 \mathrm{gm}^{-2}$ whereas the Bg 94-1 variety had $897.8 \pm 61.5 \mathrm{gm}^{-2}$ (Figure 03.a). This confirms the improved canopy architectural traits along with photosynthetic characteristic had led to display an increased capacity for biomass production. This confirms the previous study that , the variety At-362 produced with significantly higher biomass and panicle weight than the $\mathrm{Bg}$ 94-1 (Begum et al., 2018). The harvest index was compared by measuring the ratio between panicle weight and AGDM per unit land area from the trials. When compared, the harvest index of both varieties had displayed above 0.51 , which confirms that both varieties are well improved for commercial cultivation, typically for the dry zone in Sri Lanka. However, when the 100-grain weight was analyzed, no significant differences were observed. This reveals that At-362 could have produced more grains per panicle than the other variety. 

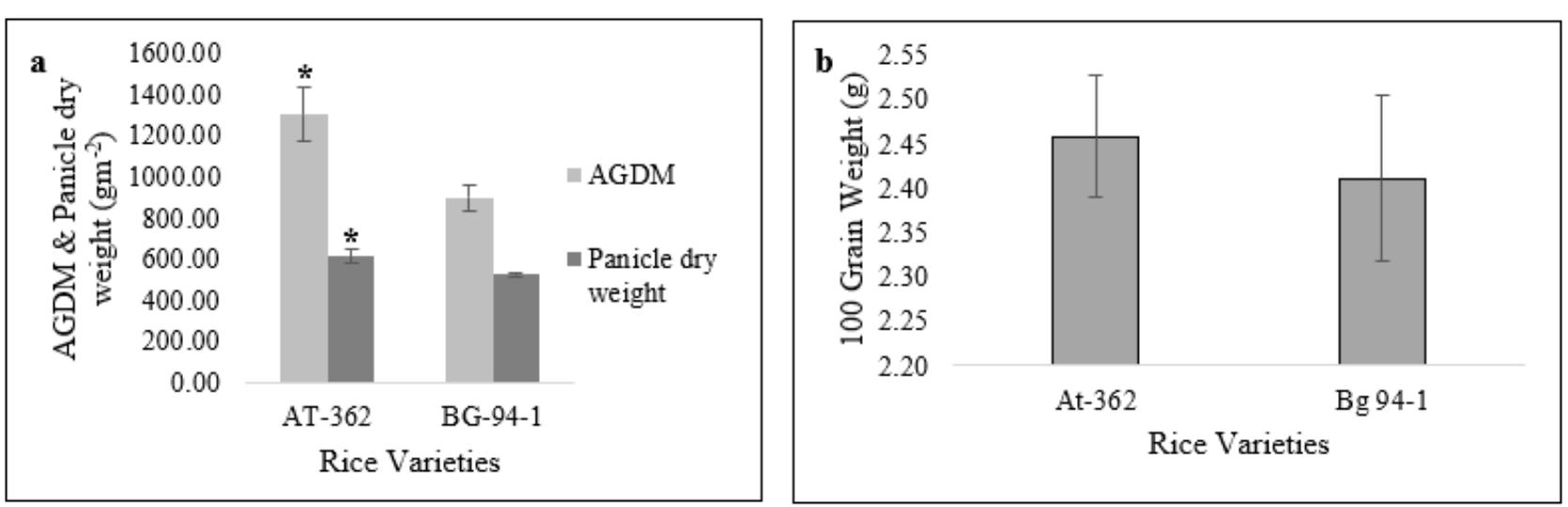

Figure 03: Dry matter production in two rice varieties. (a) Above-ground dry biomass (AGDM) and panicle dry weight $(n=22)(b)$ Dry weight of 100 grains of two varieties $(n=5)$. Error bars indicate the standard error of the mean. The symbol (*) indicates significant differences between rice cultivars ( $p$-value $<0.05$ ).

Thereby, rice yield can be increased by employing cultivars with superior morphological and physiological characteristics while maintaining an optimal cultural practice in the cropping fields. This ensures the plant growth and development of aerial and underground parts through which efficient utilization of solar radiation, water and nutrients can take place $(\mathrm{Wu}$ et al., 1998; Miah et al., 2004). Moreover, the conversion of solar radiation into useful biomass production also dependents on the contribution of canopy architecture, leaf-level photosynthesis and minimizing photo-oxidative stress exerted by individual leaves (Murchie et al., 2009). It has been reported the canopy architectures and the harvesting index for most cereals have been plateaued and novel avenues have been suggested by altering the photosynthesis properties of leaves and the canopies (Sheehy et al., 2008). Based on this expectations, numerous experiments have been conducted to alter the conventional $\mathrm{C}_{3}$ photosynthesis mechanisms possess within rice plants through mutational treatments (Nagoor, 2013), by altering the leaf vein counts (Smillie et al., 2012; Feldman et al., 2017) and even through genetic modification. However, most of the previous attempts in converting $\mathrm{C}_{3}$ rice plants into an efficient $\mathrm{C}_{4}$ photosynthetic mechanism remain a challenge owing to the complex anatomical and physiological modifications that are required.

Overall, the biomass and the harvest index in rice crops give rise from the dry matter accumulation, yield components particularly the number, size and weight of panicle characteristics, and the ability of efficient dry matter partitioning within the canopy. The source size particularly the LAI, productive tiller numbers have a direct impact on the sink size viz; spikelet numbers per panicle, chiefly determined by canopy light distribution, availability of water, and the supply of required nutrients (Singh et al., 2003; Assuero and Tognetti, 2010). Considering the above facts, the crops grown in the present field trial had the optimum growth condition, thus the variations in the morphology, physiology and biomass are attributed due to their genetic inheritance characters.

\section{CONCLUSIONS}

Canopy architecture primarily determines the amount of light (PAR) interception and extinction by crops that permits optimized photosynthesis and biomass production. Here, we showed the crop canopy architecture can be identified based on the light extinction coefficient $(k)$, in fact, lower $k$-values depict the upright leaf architecture (At362 ) and an increased $k$ represents the horizontally arranged leaves (Bg 94-1). Furthermore, this study showed that photosynthetic performance is determined by the factors other than canopy architectural traits, and an increased quantum yield with optimized stomatal conductance for rice enhances carbon gain. This observation has some profound implications for the improvement of canopy photosynthesis and resource use 
efficiency in crops. First, that farmers in the dry zone areas are advised to use upright leaf architecture with improved rice varieties (such as At-362) to ascertain productivity even though crops are exposed to harsh environmental temperature. Second, the present study explores the future avenues of employing state-of-theart technologies aided with the ceptometers, chlorophyll fluorescence technologies, porometers and instantaneous chlorophyll measurements will elucidate the underlying morpho and physiological mechanisms within plant canopies and identifies rice plants confers with improved canopies and a cellular level photosynthetic process to ensure sustainable food production.

\section{ACKNOWLEDGEMENT}

The authors wish to thank the farm supervisor Mr. Y. B. Mohamed Kamil for his valuable support throughout this field trial at AgroTech Park Malwatta, Department of Biosystems Technology, Faculty of Technology, South Eastern University of Sri Lanka. Further, we thank to technical officers and lab attendants of Department of Biosystems Technology who provided the valuable support for the laboratory analysis of this study.

\section{REFERENCES}

Ahmad, A., Iqbal, S., Ahmad, S., Khaliq, T., Nasim, W., Husnain, Z., Hussain, A., Zia-Ul-Haq, M. and Hoogenboom, G. (2009). Seasonal growth, radiation interception, its conversion efficiency and biomass production of Oryza sativa L. under diverse agro-environments in Pakistan. Pakistan Journal of Botany. 41(3), pp. 1241-1257. Retrieved from http://www.pakbs.org/ pjbot/PDFs/41(3)/PJB41(3)1241.pdf.

Assuero, S. G. and Tognetti, J.A. (2010). Tillering regulation by endogenous and environmental factors and its agricultural management. The Americas Journal of Plant Science and Biotechnology. 4(1), pp. 35-48. https://doi.org/10.1080/00288233.2012.706223.

Azam-Ali, S. N. and Squire, G. R. (2002). Principles of tropical agronomy. CABI. New York, USA. 233pp. https://doi.org/10.1079/9780851991368.0001.

Begum, S. L. R., Pavithira, E. and Mubarak, A. N. M. (2018). Contribution of growth and physiological characteristics in yield of field grown rice varieties in low country dry zone. $8^{\text {th }}$ International Symposium of SEUSL, pp. 197-204. Retrieved from http://ir.lib.seu.ac.lk/ handle/123456789/3545.

Burgess, A. J., Retkute, R., Herman, T. and Murchie, E. H. (2017). Exploring relationships between canopy architecture, light distribution, and photosynthesis in contrasting rice genotypes using 3D canopy reconstruction. Frontiers in Plant Science. 8, pp. 1-15. https://doi.org/10.3389/ fpls.2017.00734.

Campbell, G. S. (1986). Extinction coefficients for radiation in plant canopies calculated using an ellipsoidal inclination angle distribution. Agricultural and Forest Meteorology. 36(4), pp. 317-321. https://doi.org/10.1016/0168-1923(86)90010-9.

Chang, T. G., Zhao, H., Wang, N., Song, Q.F., Xiao, Y., Qu, M. and Zhu, X.G. (2019). A threedimensional canopy photosynthesis model in rice with a complete description of the canopy architecture, leaf physiology, and mechanical properties. Journal of Experimental Botany. 70(9), pp. 2479-2490. https://doi.org/10.1093/jxb/ery430. 
Department of Agriculture. (2020). AgStat: Agricultural Statistics XVII. Socio Economics and Planning Centre, Department of Agriculture. Peradeniya, Sri Lanka. 15-16. Retrieved from https://www .doa.gov.lk/ICC/images/publication/Books/Other_Bok/AgstatBK.pdf.

de Pury, G. G. and Farquhar, G. D. (1997). Simple scaling of photosynthesis from leaves to canopies without the errors of big-leaf models. Plant, Cell and Environment. 20(5), pp. 537-557. https://doi.org/10.1111/j.1365-3040.1997.00094.x.

Ewert, F. (2004). Modelling plant responses to elevated $\mathrm{CO}_{2}$ : How important is leaf area index? Annals of Botany. 93(6), pp. 619-627. https://doi.org/10.1093/aob/mch101.

Fageria, N. K. (2007). Yield physiology of rice. Journal of Plant Nutrition. 30(6), pp. 843-879. https://doi.org/10.3389/fpls.2017.01883.

Falster, D. S. and Westoby, M. (2003). Leaf size and angle vary widely across species: What consequences for light interception?. New Phytologist. 158(3), pp. 509-525. https://doi. org/10.1046/j.1469-8137.2003.00765.x.

Feldman, A. B., Leung, H., Baraoidan, M., Elmido-Mabilangan, A., Canicosa, I., Quick, W. P., Sheehy, J. and Murchie, E. H. (2017). Increasing leaf vein density via mutagenesis in rice results in an enhanced rate of photosynthesis, smaller cell sizes and can reduce interveinal mesophyll cell number. Frontiers in Plant Science. 8, pp. 1-10.https://doi.org/10.3389/ fpls.2017.01883.

Food and Agriculture Organization. (2017). FAO/WFP Crop and food security assessment mission to Sri Lanka. Food and Agriculture Organization of the United Nations World Food Programme. Italy. 28-29. Retrieved from https://www.fao.org/resilience/resources/resources-detail/ en/c/897798/.

Food and Agriculture Organization. (2018). Rice Market Monitor. http://www.fao.org/economic/est/ publications/rice-publications/rice-market-monitor-rmm/en/. 20.04.2019.

Goudriaan, J. (1977). Crop micrometeorology: A simulation study. Ph.D. Thesis, Ecology of the Agricultural University, Wageningen, Netherlands. 249pp.

Hirose, T. (2005). Development of the Monsi-Saeki theory on canopy structure and function. Annals of Botany. 95(3), pp. 483-494.https://doi.org/10.1093/aob/mci047.

Ho, C., Yang, C., Hsiao, C. and Lai, M. (2013). Changes of climatic variables during grain-filling stage affect yield and quality of rice cultivars bred from different regions in Taiwan. Journal of Taiwan Agricultural Research. 62(4), pp. 321-339. https://doi.org/10.6156/JTAR/2013.06204.03.

Hou, H. J. M., Najafpour, M. M., Moore, G. F. and Allakhverdiev, S. I. (2017). Photosynthesis: Structures, Mechanisms, and Applications. Springer Nature, Cham, Switzerland. 424pp. https://doi.org/10.1007/978-3-319-48873-8.

Khalifa, A. (2009). Physiological evaluation of some hybrid rice varieties under different sowing dates. Australian Journal of Crop Science. 3(3), pp. 178-183. Retrieved from http://www. cropj.com/khalifa_3_3_178_183.pdf.

Lawson, T. and Matthews, J. (2020). Guard Cell Metabolism and Stomatal Function. Annual Review of Plant Biology. 71(1), pp. 273-302.https://doi.org/10.1146/annurev-arplant-050718-100251. 
Miah, M. N. H., Talukder, S., Sarkar, M. A. R. and Ansari, T. H. (2004). Effect of number of seedling per hill and urea super granules on growth and yield of the rice cv. BINA dhan4. Journal of Biological Sciences. 4(2), pp. 122-129. Retrieved from http://docsdrive.com/pdfs/ansinet/ jbs/2004/122-129.pdf.

Monsi, M. and Saeki, T. (1953). Ober den Lichtfaktor in den Pflanzengesellschaften und seine Bedeutung fur die Stoffproduktion. Japanese Journal of Botany. 14, pp. 22-52. Retrieved from https://ci.nii.ac.jp/naid/10010349537/en/

Monteith, J. L. (1965). Light distribution and photosynthesis in field crops. Annals of Botany. 29(1), pp. 17-37.https://doi.org/10.1093/oxfordjournals.aob.a083934.

Murchie, E. H., Pinto, M. and Horton, P. (2009). Agriculture and the new challenges for photosynthesis research. New Phytologist. 181(3), pp. 532-552. https://doi.org/10.1111/ j.1469-8137.2008.02705.x.

Nagoor, M. M. A. (2013). Analysis of novel photosynthetic traits in a rice deletion mutant population. Ph.D thesis, The University of Nottingham, Nottingham, UK. 205pp.

Nobel, P., Forseth, I. and Long, S. (1992). Canopy structure and light interception, in Hall, D. et al. (eds). Photosynthesis and Production in a Changing Environment: A field and laboratory manual. Springer, Dordrecht, Netherland. pp. 79-90. https://doi.org/10.1007/978-94-0111566-7_6.

Normile, D. (1999). Crossing rice strains to keep Asia's rice bowls brimming. Science. 283(5400), pp. 313-313. https://doi.org/10.1126/science.283.5400.313.

Peng, S. (2000). Single-leaf and canopy photosynthesis of rice. Studies in Plant Science. 7(2000), pp. 213-228. https://doi.org/10.1016/S0928-3420(00)80017-8.

Pokovai, K. and Fodor, N. (2019). Adjusting ceptometer data to improve leaf area index measurements. Agronomy. 9(12), pp. 866-879. https://doi.org/10.3390/agronomy9120866.

Pradhan, S., Sehgal, V. K., Bandyopadhyay, K. K., Panigrahi, P., Parihar, C. M. and Jat, S. L. (2018). Radiation interception, extinction coefficient and use efficiency of wheat crop at various irrigation and nitrogen levels in a semi-arid location. Indian Journal of Plant Physiology. 23(3), pp. 416-425.https://doi.org/10.1007/s40502-018-0400-х.

Roupsard, O., Dauzat, J., Nouvellon, Y., Deveau, A., Feintrenie, L., Saint-André, L., Mialet-Serra, I., Braconnier, S., Bonnefond, J. M., Berbigier, P., Epron, D., Jourdan, C., Navarro, M., and Bouillet, J.P. (2008). Cross-validating Sun-shade and 3D models of light absorption by a tree-crop canopy. Agricultural and Forest Meteorology. 148(4), pp. 549-564. https://doi.org/ 10.1016/j.agrformet.2007.11.002.

San-oh, Y., Oclarit, R. P., Ookawa, T., Motobayashi, T. and Hirasawa, T. (2006). Effects of planting pattern on the interception of solar radiation by the canopy and the light extinction coefficient of the canopy in rice plants direct-sown in a submerged paddy field. Plant Production Science. 9(3), pp. 334-342. https://doi.org/10.1626/pps.9.334.

San-oh, Y., Oclarit, R. P., Ookawa, T., Motobayashi, T., and Hirasawa, T. (2008). How the rice crop works and why it needs a new engine', in Sheehy, J.E., Mitchell, P.L., and Hardy, B. (eds) Charting new pathways to $\mathrm{C} 4$ rice. International Rice Research Institute, Philippines. pp. 3-26. https://doi.org/10.1142/9789812709523_0001. 
Singh, V.K., Dwivedi, B.S., Shukla, A.K. and Yadav, R.L. (2003). Effects of nitrogen and phosphorus fertilization on the growth and yield of rice (Oryza sativa) and wheat (Triticum aestivum) as influenced by the inclusion of forage cowpea (Vigna unguiculata) in the rice-wheat system. Indian Journal of Agricultural Science. 73, pp. 482-489. Retrieved from https://www. semanticscholar.org/paper/Effect-of-nitrogen-and-phosphorus-fertilization-on-Singh-Dwived $\mathrm{i} / 43 \mathrm{~cd} 17146 \mathrm{ed} 3 \mathrm{db} 49 \mathrm{e} 3 \mathrm{c} 05 \mathrm{e} 14 \mathrm{ec} 0 \mathrm{e} 6 \mathrm{c} 76 \mathrm{a} 83 \mathrm{fbde} 9$.

Smillie, I. R. A., Pyke, K. A. and Murchie, E. H. (2012). Variation in vein density and mesophyll cell architecture in a rice deletion mutant population. Journal of Experimental Botany. 63(12), pp. 4563-4570. https://doi.org/10.1093/jxb/ers142. Epub 2012 Jun 8.

Song, Q., Chu, C., Parry, M. A. J. and Zhu, X. (2016). Genetics-based dynamic systems model of canopy photosynthesis: the key to improve light and resource use efficiencies for crops. Food and Energy Security. 5(1), pp. 18-25.https://doi.org/10.1002/fes3.74. Epub 2016 Jan 4.

Taiz, L., Zeiger, E., Møller, I. M. and Murphy, A. (2015). Plant physiology and development. $6^{\text {th }}$ edn. Oxford University Press. USA. 761pp.

Virk, P. S., Khush, G. S. and Peng, S. (2004). Breeding to enhance yield potential of rice at IRRI: The ideotype approach. International Rice Research Notes. 6(5), 467-478.http://dx.doi. org/10.4236/as.2015.65046.

Wu, G., Wilson, L. T. and McClung, A. M. (1998). Contribution of rice tillers to dry matter accumulation and yield. Agronomy Journal. 90(3), pp. 317-323. https://doi.org/10.2134/agronj1998.00021 $962009000030001 \mathrm{x}$.

Wu, A., Song, Y., van Oosterom, E. J. and Hammer, G. L. (2016). Connecting biochemical photosynthesis models with crop models to support crop improvement. Frontiers in Plant Science. 7, pp. 1-16. https://doi.org/10.3389/fpls.2016.01518.

Yu, H., Murchie, E. H., González-Carranza, Z. H., Pyke, K. A. and Roberts, J. A. (2015). Decreased photosynthesis in the erect panicle 3 (ep3) mutant of rice is associated with reduced stomatal conductance and attenuated guard cell development. Journal of Experimental Botany, 66(5), pp. 1543-1552. https://doi.org/10.1093/jxb/eru525. Epub 2015 Jan 11.

Zhang, L., Hu, Z., Fan, J., Zhou, D. and Tang, F. (2014). A meta-analysis of the canopy light extinction coefficient in terrestrial ecosystems. Frontiers of Earth Science. 8(4), pp. 599-609. https://doi. org/10.1007/s11707-014-0446-7. 